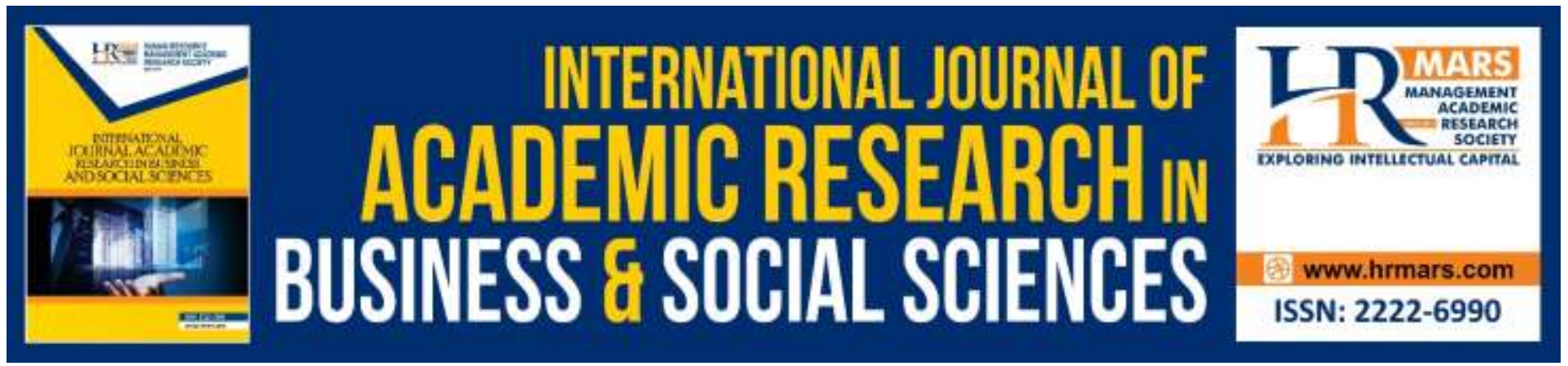

\title{
Sino-US Competition in Asia Pacific through the Lens of Power Transition Theory
}

\section{Sobia Jamil, Syed Zohaib Abbas Rizvi, Abdullahi Ayoade Ahmad,' Nasa'i Muhammad Gwadabe}

To Link this Article: http://dx.doi.org/10.6007/IJARBSS/v9-i6/5919

DOI: $10.6007 /$ IJARBSS/v9-i6/5919

Received: 10 March 2019, Revised: 20 April 2019, Accepted: 21 May 2019

Published Online: 24 June 2019

In-Text Citation: (Jamil, Rizvi, Ahmad \& Gwadabe 2019)

To Cite this Article: Jamil, S., Rizvi, S. Z. A., Ahmad, A. A., Gwadabe, N. M. (2019). Sino-US Competition in Asia Pacific through the Lens of Power Transition Theory. International Journal of Academic Research in Business and Social Sciences, 9(6), 44-57.

Copyright: (c) 2019 The Author(s)

Published by Human Resource Management Academic Research Society (www.hrmars.com)

This article is published under the Creative Commons Attribution (CC BY 4.0) license. Anyone may reproduce, distribute, translate and create derivative works of this article (for both commercial and non-commercial purposes), subject to full attribution to the original publication and authors. The full terms of this license may be seen at: http://creativecommons.org/licences/by/4.0/legalcode

Vol. 9, No. 6, 2019, Pg. 44 - 57

http://hrmars.com/index.php/pages/detail/IJARBSS

JOURNAL HOMEPAGE

Full Terms \& Conditions of access and use can be found at http://hrmars.com/index.php/pages/detail/publication-ethics 


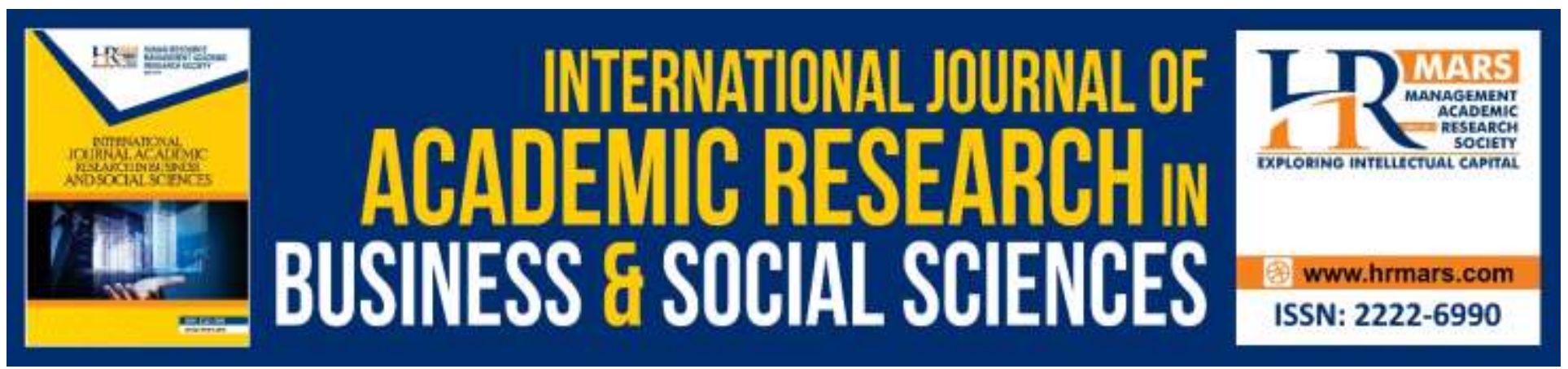

\title{
Sino-US Competition in Asia Pacific through the Lens of Power Transition Theory
}

\author{
Sobia Jamil ${ }^{1}$, Syed Zohaib Abbas Rizvi², Dr. Abdullahi Ayoade \\ Ahmad ${ }^{1}$, Nasa'i Muhammad Gwadabe ${ }^{1}$ \\ ${ }^{1}$ Department of International Relations, Universiti Sultan Zainal Abidin, Malaysia \\ ${ }^{2}$ Department of Political Science, University of Punjab, Pakistan
}

Email: sobiajamil09@gmail.com, abdullahiayoade@unisza.edu.my, abbas.zohaib110@gmail.comn, ngwadabe@gmail.com

\begin{abstract}
Asia Pacific is a region with intricate scenarios. On the one hand, there is an unabated region-wide drive for economic development that has been pushing Asia-Pacific forward for decades. On the other hand, this region is troubled with, aside from many other conflicts, unsettled maritime disputes that have the potential to trigger wars between and among the Asia-Pacific nations. On top of these varied scenarios, there is powerful struggle between China and the United States over a wide range of vital geopolitical, geostrategic and geo-economic interests in this region. For better or for worse, the U.S.-China relationship is becoming a defining factor in the relations among the Asia-Pacific nations. The US is struggling in adopting right strategy and policy choices to deal with emerging China. Sino-American ongoing rivalry can be explained by several theories but the purpose of this paper is to analyze the power transition and the possibility of power transition in the $21^{\text {st }}$ century by viewing Sino-US competition particularly in Asia pacific region which is, to a gradual extent, influencing the future of global politics. In the future there is strong possibility of increasing shakiness in the Asia- pacific region because of Sino-U.S power struggle. As a result, the paper evaluates the impact of ongoing rivalry between China and US on Asia Pacific using the lens of power transition theory and investigates the factors behind US's policies towards the region.
\end{abstract}

Keywords: Asia Pacific, China, Geo-economics, Geostrategic, Power Transition, United States

\section{Introduction}

There was ideological conflict between United States of America and former Soviet Union during the Cold war era. At the time, both of them adopted every technique whether it is domestic or regional, conventional or unconventional to pursue the conflict. It was an ideological clash between two solid and different political ideologies. The Cold war era ended in 1991 at the expense of the 
Soviet Union break up and US emerged as the sole super power. But with the start of $21^{\text {st }}$ century, the world is experiencing a huge economic shift(Tehseen, 2017).

Numerous world leaders and scholars have already stated that the $21^{\text {st }}$ century is an 'Asian Century(Hsiung, 2008). The $21^{\text {st }}$ century is the first time in several hundred years, when the importance of the Trans- Atlantic has shifted to Trans- Pacific as the centre of geopolitics and geoeconomics and is experiencing new role as a global centre for geopolitical, economic and military competition of great powers and it has enhanced the importance of regional organizations (ASEAN, SAARC, SCO, BRICS)(Chan, 2013).

Admittedly Asia is facing a number of structural challenges but still has a good chance of achieving in this century a greater degree of progress and development to other regions. $(\mathrm{Pu}, 2013)$ It is a region of stunning economic growth with emerging powers like China, having expanding markets of trade, investment and strategic maritime shipping routes connecting pacific with the Indian Ocean(Pu, 2013).

China is the only country widely seen as a possible threat to U.S. predominance. Indeed, China's rise has led to fears that the country will soon overwhelm its neighbors and one day supplants the United States as a global hegemon. China has now the economic and technological influence all over the world. The factors that contribute to China's rise are Beijing's economic strategy and its diplomatic magnification at global level. Having learnt from Soviet Union and Japan, China did not demonstrate her military capability to compete with the US. It is one of the leading states with $6.58 \%$ average annual growth rate and it is anticipated that its economy can overtake United States by $2039(\mathrm{Pu}, 2013)$ and Economic power will increasingly move away from Western Europe and North America to Asia Pacific.

This Economic shift is going to have a great impact on geo- political situation of the Asia Pacific region. China has come up with great economic strategy with the Belt and Road Initiative (BRI) to enhance connectivity and its influence in different regions(Cai, 2017). The rise of China with this economic strength is inevitable. Like many other powers, China is also upgrading it military power as the Chinese military is deploying huge number of missiles, hard to find submarines, long range sensors to track anti-satellite weapons, digital networks to coordinate attacks and cyber war weapons to catch opponent's networks(Liff \& Erickson, 2013). This emergence of China as a strong contender would result in a power shift from the declining power of the US and European states. However, comparatively Russia, United Sates of America and Western countries would remain stronger in military terms than China.

Therefore, U.S views any military upsurge by China with suspicion. The nature of the emerging multi-polarity is such that the US has to face this challenge posed by the regional predominance of China in the Asia-Pacific region(Jisi, 2011). On the contrary, the US is also confronted with the Russian involvement in the Middle East and the Eastern European regions. This study analyzes the impact of Sino-US competition on the strategic stability of Asia Pacific. There is hard power projection by both China and the US in the South China Sea. China is very much assertive and it can be analyzed clearly by its assertive acts and sometimes tougher stands towards United States(Hossain, 2013). However, hostilities have not broken out between the US and China so far. The US and China are playing a geo-political chess game in the Asia-Pacific region.(Glaser, 2012) 
In 2010 Obama administration initiated its 'pivot' to Asia; a shift in the strategy aimed at increase its military presence in the Asia Pacific(Campbell \& Andrews, 2013). Basically the main objective of militarist policy of the US is to maintain its post world war II dominance over the Asia pacific. Asia pivot strategy made it clear that major focus of U.S is to strengthen US strategic and military alliances to encircle China and to defeat its capabilities(Logan, 2013). However President Obama rejected this view that the aim of Rebalancing Asia is containing China. The Obama administration was determined to expand America's influence with an extensive network of trade and investment and develop new partnerships among the major regional economic powers to hedge China on the Asian Framework(Manyin et al., 2012).

In 2016, Republican Party won the elections in U.S and it indicated a shift in US policies towards Asian region. As Trump administration decided to pulls out America from Trans Pacific Partnership(Miller, 2017), U.S's economy and its international standing on world issues are declining. US is facing huge economic challenges due to economic stagnation at home and rising Gross Domestic Product (GDP) in the Asian states. China's continuous growing economic strength and its BRI initiative for global connectivity has created an opportunity for it that it could leave behind the economies of the North American and West European countries. If this happens, then China would be in a position to challenge the economic and possibly, the political leadership within regional organizations and international regimes. The Trump administration, despite its disagreement with the Asian tools of President Obama's foreign policy, he could not fully ignore the region. Trump's decision of withdrawing from the Trans Pacific Partnership (TPP) is a blow to the economic element in the region("Trump signs executive order to withdraw US from Trans-Pacific Partnership," 2018). Now the Trump administration would be forced to rely on a 'military-only' approach towards the region. Nonetheless, a reliance on soft power in the Asian region would make US compete with various Chinese soft power initiatives in the region.

\section{Power Transition Theory}

International relations analysts have often sought to explain the state interactions, events and phenomena of world politics in context of various theoretical frameworks. International theories help in developing the conceptual framework upon which states relations can be analyzed.

Organski (1958) introduced power transition theory in his classic work, World Politics.(Organski, 1958) Power transition is a hegemonic theory and a structural and vibrant approach to international affairs. It focuses on power relationships so sometimes it is linked to realist school of thought but unlike realist theories, it focuses on the role of dominant state in managing the status quo and deemphasizes the role of anarchy. Power transition sees global politics as a hierarchy of nations with altering levels of cooperation and competition. There is always uneven distribution of power among independent sovereign nations. Some nations are more powerful than others are in terms of size and level of development.

Power transition theory has three components: structure, dynamics and policy. According to power transition theory, international system is hierarchical in which domination nation sits at the top. As Organski observes, "at any given moment the single most powerful nation on earth heads an international order which includes also some other major powers of secondary importance and some minor nations and dependencies as well.(Lai, 2011)" 
It challenges the realist theory of balance of power, which says that balance of power is more favorable for world peace than the imbalance of power whereas power transition argues that a balance of power does not lead to peace among international powers. To the contrary, power parity leads to war, especially when one great power overtakes the dominant power in the international system(Kugler \& Lemke, 1996). Organski and Kugler (1980) explain that level of satisfaction and dissatisfaction matter for the maintenance of the status quo(Organski, 1980).

If the states are satisfied with the status quo, they may ally with the dominant power for economic and security support and normally the dissatisfied states are too weak and unable to stand in front of the dominant power, but if the power of rising sate approaches that of the dominant state, then that state will initiate a war to change the status quo. Therefore, war is more likely when the challenger is dissatisfied and surpasses the dominant power or there is parity between the dominant power and the challenger.

According to power transition, imbalances in power can be more conducive to peace and power parity is dangerous(Tammen et al., 2000). Power transition theorists mainly focus on great power conflict but it can be applied on regional players as well. Distribution of power is uneven between the states in any given region as it is spread unevenly across the world.

Power transition theory can be used to better understand power dynamics and the likelihood of war in a specific region or internationally. It requires a scientific definition of power for its application to real world cases. The primary theorists of the theory define power as the ability of a state to impose on or persuade another state to comply with its will(Organski \& Kugler, 2015).

Power is achieved through the combination of a state's population, this population's economic productivity, and the ability of its government to mobilize the former two effectively and efficiently (Keohane \& Nye, 1977). Each of these three components is necessary for a state to reach great power status, and therefore, potentially challenge the dominant power.

Power transition mainly focuses on the satisfaction of states with the international system because according to power transition, War occurs because of three conditions: Power shifts, approximate equality of power and Dissatisfaction with the status quo (DiCicco \& Levy, 1999). Dominant powers try to maintain their hegemony and satisfied status quo by developing a system acceptable to other states. Sometimes dominant power compromises on her hegemony and control over system for creating an environment of mutual trust and benefit otherwise satisfied lesser powers would be skeptical or hostile to dominant power. Satisfied states will support and dominant power will be able to maintain its status quo peacefully rather than by persistently enforcing its will(Efird, Kugler, \& Genna, 2003).

Approximate equality of power is dangerous and it can create instability if the rising state is dissatisfied with the status quo established by the dominant power. Dissatisfaction can be based on historical, ideological, religious, territorial, personal, cultural or any other issue. Challenger will not initiate war until being stronger and has relative power to the dominant state. Unlike Balance of power, Power transition theory explains power as a combination of population, economic production and political power to influence the other state's decision making process.

In other words, power of states increases with the industrialization and with this process states will be able to catch up the dominant state because dominant state has diffident growth and rising 
state has rapid growth because of industrialization but again for taking the initiative of war, challenger must be dissatisfied from the existing status quo established by dominant power.

According to Christopher Layne, "a theorist" new leading power emerges because of differential rates of growth and it eventually leads to shift in power. The potential challenger if dissatisfied will try for the transition into becoming the dominant state (Layne, 1998). The question arises that will this transition will be peaceful or violent? According to a study conducted by Rapkin and Thompson, the future of such conflict is uncertain.

Power transition theory argues that rising state is more like to initiate the war with dominant power or vise versa. According to Organski and Kugler, war will happen after the transition but Ronald L. Tammen has different view. He suggests that rising power will take the initiative after the point of transition (Lemke \& Tammen, 2003). Levy and Thompson made an argument to challenge Organski's point of view and they state that rising state would be weaker for taking the initiative of war but it would be much stronger to confront the dominant power after the point of transition(DiCicco \& Levy, 1999). Then the question is why dominant power would wait for the challenger to strike the dominant state?

If the dominant state initiates' war this would be called preventive war. A preventive war is very much different from preemptive one. The difference is that preventive war would be initiated because of having fears of a rising opponent, shift in power by the fear that if the challenger will become stronger, through war and coercion it will attempt to exploit its advantage. This war is motivated by the anticipation of power shift unlike preemption because it is not motivated by the expectation of an immediate attack.

In preemption, there is certainty that rising challenger would attack first and get the advantage of striking first. According to preventive logic, a shift in power leads to war but if we take examples from history, it shows us different view. For example, United States of America surpassed Britain as a global power in the $20^{\text {th }}$ century and in 1930's Germany was rapidly rising and it met with appeasement. Power shift did not lead to preventive war in both cases(Tammen \& Kugler, 2006).

Power transition theory is completely opposite to balance of power. Each theory focuses on different kinds and systems of power but both focus on power relationships with in the international system. Power dynamics that each theory hypothesizes can be summarized as Power transition theory define power in terms of population wealth, economic productivity and political capacity. Unlike power transition theory, balance of power focuses on military power only. To further elaborate the difference between theories: According to Balance of power, it is more conducive to peace and it views application of power as eliciting balancing alliances and major wars while power transition theory states that approximate parity of power is dangerous and leads to war and it views concentration of power in a single dominant power in the international system as stabilizing but transition of power between the dominant power and rising challenger can be the cause of instability in international system.

\section{Real Contender through the lens of Power Transition Theory}

Power transition theory is very useful to understand the future of world politics and relations of dominant states. Power shifts and the associated war and peace periods support the central idea of power transition theory that imbalance in power maintains the world order and peace and 
INTERNATIONAL JOURNAL OF ACADEMIC RESEARCH IN BUSINESS AND SOCIAL SCIENCES

Vol. 9, No. 6, June, 2019, E-ISSN: 2222-6990 @ 2019 HRMARS

approximate parity in power breeds great power war. The main question is that if one or more nations are rising at the same time then how would a dominant nation identify the challenger? For example, United States of America and Germany both were expanding their national power and were rising spectacularly. They surpassed Britain but why did Great Britain only singled out Germany?

In $21^{\text {st }}$ century China, India and Brazil are rising simultaneously and one has to consider a resurgent Russia. EU is also becoming an alarming actor on the world stage and finally Japan will emerge as an important factor in world's security and political affairs. The actual question that arises is that which one of thesis rising states is a real contender?

According to power transition theory, there are two basic requirements to become a potential challenger. These requirements are challenger must be the strongest one among second-ranked nations in geographic and demographic measures and it should be dissatisfied from the existing status quo. These two requirements make sure that the contender has the will and capacity to change the existing status quo established by dominant power.

The term dissatisfaction is subjective. Organski also provided the two objective ways to deal with the subjective term of dissatisfaction. First one is that dissatisfied challenger is not an ally of the dominant state. Second one is that challenger is not satisfied with the existing world order and finds this system against its own interests and it has no part in creating the existing world order so if it becomes more powerful, it will make an effort to change it according to its own interests(Lebow \& Valentino, 2009).

Brazil, Russia, India and China are the second-ranked nations and they came to the spotlight of world attention when a report entitled "Dreaming with BRIC's: The path of 2050" was published. This study was by the American Gold men Sachs Group, Inc. According to the report, these four countries occupy more half of the world's landmass, consist of 40 percent of the world's population and they are experiencing high rapid economic growth(Wilson \& Purushothaman, 2003). Economies of G7 countries (US, Germany, Japan, UK, France, Italy, and Canada) could be eclipsed by the combined economies of BRIC's.

Now the question is that which one of these four countries is a real contender for the next dominant power or will the BRIC's collectively rule the world? Indeed the heads of BRIC's have issued a declaration for the establishment of multi polar world order during their first summit in Yekaterinburg, Russia on June 16, 2009 (Halpin, 2009). They focused on issues like climate change and global financial system in their second summit held in Brazil in April 2010. BRIC's foreign ministers have been meeting annually since 2006. Heads of central bank and financial ministers also have held frequent meetings. To disqualify Russia and exclude India and Brazil as the serious contenders of world's next dominant power, there are many good reasons

There is no doubt that Russia is a dissatisfied second-ranked nation and after losing the Cold war, US and Western countries have not been able to transform Russia into a great supporter. Russia's transition from communism into democracy is still questionable(Macfarlane, 2006). U.S and West still have fears over the resurgent Russia. Russia is not happy with this kind of treatment by US and Western countries and is determined that eventually, it will restore her great power status. Although Russia will make alarm bells ring in the coming future, but the contemporary resurging Russia poses no serious threat (at least economic) for world leadership. With soviet style 
communism, Russia has no political, economic or cultural substitutes to offer the world.(Parker, 2011) With a heavy dependence on energy (gas and oil) exports and a budget formed on the intricacies of OPEC betting of oil prices, Moscow's economy would take time to challenge the likes of Japan and Germany.

Next state is India. India needs strong partners like US, Russia and Japan to counterbalance China's influence in the region. In the same case, U.S also needs India in dealing with the Chinese threat as Fareed Zakaria states that "India will be a check on China's rising ambitions and a natural ally of United States of America (Zakaria, 2009)." Brazil is also a satisfied second-ranked power. It is a country with the abundance of natural resources, controllable population as compared to its fellow states India and China, free of territorial disputes and a running political and economic system. The argument to prove China doing differently than India, Russia and Brazil is its magnanimous economic stature. By no means could we infer that the three countries are showing incompetency for a bigger role, but we could deduce the deductibility of the Chinese speculation cum feasibility ie China would attain the super power status much earlier than India, Brazil and China. The contemporary world demands a super power to have an edge in economy and military power: China has achieved the first part in a bid to equate/ surpass the US in the coming decade or two; Beijing's military establishment needs to catch up the US train in the latter case. China is a dissatisfied, second ranked nation and has a potential greater than all the other same status major powers. It is not an ally of US and has not played any role in establishing the current world order.

\section{China's Economic Outlook and Military Modernization}

China's journey to progress starts with Deng Xiaoping's four-point modernization policy in 1978. The Chinese Communist Party adopted the export-oriented policy of Japan, South Korea Hong Kong and Singapore and soon emerged as a factory of world. China started to make consumer products by the mid 1990's and since then, China sustains its economic growth with approximately a double figure growth rate. It has not only showed a remarkable growth rate, but is also driving world economies around the world. Economic policy of China has become a source of inspiration for other developing countries. It has brought a revolution of exports. There is hardly any country in the world where one cannot find any product having a stamp of "made in china". Its economy lifted approximately lifted 400 million people above the poverty line with in 25 years(Bergsten, Freeman, Lardy, \& Mitchell, 2008). China has become the second largest economy and its trade with its neighboring countries has been surprisingly increased. For the last few decades, China is a recordholder country of most foreign direct investment (FDI). Hongkong and Shanghai banking cooperation estimated that bank assets in China will surpass those in the United States in 2034, while Goldman Sachs estimates that China's GDP will surpass that of the United States by 2045 (Kang, 2007). Fogel, a Nobel laureate in economics predicts that China's economy will reach $\$ 123$ trillion by 2040(Fogel, 2007). All this growth is because of giving favorable conditions created through economic reforms and implementation of well-planned strategy by China's government.

According to defensive realists, a country will upgrade its military so that its reaches the point of parity or at least near-parity with its immediate rival. In other words, a state strives to attain minimum credible deterrence with the purpose to create a theatre denial capability. China's defense budget was $\$ 174.6$ billion in 2018 . Therefore, along with the economic progress, China is 
modernizing its military. Most Chinese analysts defend its continued double-digit growth in defense budget by stating that China is a vast country with a large coastline, vast land, four nuclear neighbors and the fours disputed areas in its proximity. Therefore, China's defense spending is in accordance with its need to defend the mainland and it would continue the process of modernization of its forces, which also includes a buildup of powerful naval fleet and air bases.

Chinese premier Li Keqiang said:

"China will continue to expand its air and a naval defense capability as its national security is undergoing changes. China will advance all aspects of military training and war preparedness, and firmly and resolvedly safeguard national sovereignty, security and development interests"(Dobbins, 2012)

China has been implementing its new defense strategy of military modernization and organizational reforms since 2016 and the intention is to transform its military to conduct joint operations along with other countries and resolve regional conflicts. China has established its first overseas military base in 2018 in Djibouti (Kleven, 2015). Though the Chinese state media claims it to be a nonmilitary base and an economic extension for logistics' support, things in reality seem to be different with 23,000 square meters underground military facility along with heavy fortifications. The Horn of Africa offers commercial oil passage interests to big powers: Italy, Japan, France and the US (Camp Lemonier with 4,000 soldiers) also possess military bases in Djibouti (Downs, Becker, \& DeGategno, 2017). Beijing has loaned and invested in Djibouti in its domestic hydropower and pipeline projects and the Djibouti-Ethiopia railway track, so it intends to have a long stay there countering not only the neighboring Somalian pirates but also the US influence in the Bab-el-Mandeb Strait, world's fourth most important checkpoint of imports and exports of oil. China's Military modernization strategy has started challenging the US overseas interests reaching up to East Africa from the controversies of the South China Sea.

Some of the reforms that include in China's military strategy are setting up theatre commands, joint operations command centre and developing the strategic support force to combine its space, cyber and electronic warfare elements. China is also expanding its cultural influence. It is promoting education all over the world and has established the biggest scholarship network, inviting scholars and professionals from all over the world and strengthening its multilateral alliances. The Confucius teachings have promoted in the neighboring regions through development of Confucius Institutes in Europe, Africa, Asia and North America. End of bipolarity and economic growth are the most significant reasons of China's rise. This rise has become an important topic of debate in the post 9/11 era. The question now is how China manages its rise and the power transition with the United States?

\section{US-China Power Transition}

In contemporary international issues, Sino-US power transition process is on top of all issues, on which future of international relations is based. Both countries are engaged in power transition and both countries are willing to blaze a new path out of deadly contest for peaceful future but history of power transition is full of bloodshed. Although United States and China have good intentions for 
peaceful future but both countries have many debatable and unsettled issues and if not managed properly then both countries can be engaged in an unwanted war against each other. Future Sino US relations could be seen in three ways. The first one is that China would go for a war against US but it seems impossible, as China does not want to go for a war against any country, as it would disrupt its economic development. The first scenario is a hypothetical over-generalization of a USChina war over dominance. This is a supposed extension of Mearsheimer's theoretical impossibility of a peaceful rise into a non-peaceful resistance. The second scenario is an amiable one with the two powers opting for a dialogue, cooperation and issues' resolving via peaceful talks. The last hypothesis is of a continuation of the status quo: Beijing could make every effort to gain utmost advantages under the current America's hegemony until it would become strong enough to develop its own world order. According to Mearsheimer, offensive realism stipulates that a peaceful rise is not possible for China, and it is very much possible that US would engage itself in strategic competition with China by developing strategic partnerships and alliances with the regional states to contain China for example U.S's strategic partnership with India, Japan and South Korea(Mearsheimer, 2001).

Next 30 years are very important for china's development and evolution of US-China power transition. According to Organski, power transition is a long process and it takes time to complete. For instance, in almost 70 years, Germany caught up with Great Britain. The transition of power from Britain to United States also took more than a century From last 30 years, conditions of another power transition are also taking place and it will take another 30 years for building a new world order so next 30 years are more crucial for Sino-US relations.

\section{"We can't predict with certainty what the future will bring, but we can be certain about the issues that will define our times. And we also know this: The relationship between the United States and China will shape the 21st century (President Barack Obama)(Huisken, 2009)}

This is quite a calculated statement of the US-China relationship. President Obama admitted that now United States is not a sole power to shape the world. China has emerged as a global player in world politics, so they have to invite China to help with the mission. Interestingly, United States is responsible for China's initial changes. About 40 years ago, President Richard Nixon visited China and brought China out of its self-imposed seclusion. America helped China's economic development by providing it access to US's and worldwide markets and business investments in China.

America adopted this engagement policy for many reasons. First, to eliminate hatred factor between the two nations, because both countries remained enemies for a long period, such as the United States did not recognize China after the independence for 30 years(Fairbank \& Goldman, 2006). Second was because of rivalry with Soviet Union; US supported China to create strategic balance in the region. The third one was a long-term goal. US expected that political regime would be changed because of economic development and after transforming into a democratic state, it would become an ally of US rather than an enemy. This engagement strategy served US interests 
until Cold war ended because in spite of heavy pressure for political change from US, China continued communist rule. As the result of Cold war, ideological divide had restored between the two nations and this change affected China's rise.

China and US conflict came on surface in Taiwan Strait crisis of 1995-96 when Taiwan held its first presidential election and the major motive was to get independence from mainland China. China fired missiles near Taiwan to prevent Taiwan's pro-independence forces. U.S has been involved in China-Taiwan dispute since its beginning in 1949. It supported Taiwan and made some commitments to defense Taiwan through treaties, e.g. Mutual Defense Treaty of 1954 and Taiwan Relations Act of 1979. US invoked two of these commitments made in Taiwan Relations Act by sending two aircrafts carrier battle groups to the troubled waters. It was the largest show of US combat forces in the Western pacific since the end of World War II although the crisis ended with peaceful negotiations but its consequences continued to affect US-China relations.

Pertinent Asian countries have specific inclinations towards China and US. Pakistan for example would continue to rely on the US for military equipment and assistance, but its natural alliance would go with the Chinese irrespective of Beijing's take on conservative Muslim sensitivities. Similarly, India in a US attempt to balance China would never desire to see a China controlling things in the region. A continuity of US hegemony would benefit New Delhi. US earlier stance on Prime Minister Modi including a ban on his US entry had to be changed accommodating its national interests with the Indian government. Japan though being humiliated by the dropping of US atomic bombs in WWII sides by it against China in the disputed Islands of Senkaku. South Korea in an attempt to normalize relationship with the North has seen President Trump sitting beside the North Korean leader Kim Jong-un. Though Pyongyang is closest to Beijing for decades amid international isolation, still Seoul relies heavily upon Washington to assuage the situation. These few examples of the Asian countries vis-à-vis the US-China controversy reflects upon the fact that the individualistic interests supersede any religious, ideological or ethnic inclination.

\section{Conclusion}

China threat debate quickly emerged when signs of power transition between China and US came to the surface and the most significant was China's economic growth. This debate dominated US and Western discussion of world politics. "China rising" and "China threat" quickly became synonymic buzzwords in the US media, academic and policy circles. Let us conclude by referring to the tragedy of great power politics by Mearsheimer discussing the Chinese threat. He provided a theoretical explanation. International system is anarchical and the most important need of states is survival. For survival, states need to maximize their national power. Great powers in any particular region have more needs because they want to be the strongest in their own region and then of course they strive to create the global hegemony. Hunger for power, dominance and regional hegemony in international politics are unmatched. This urge initiates a struggle for global hegemony vis-a-vis great power competition. There are two common things, which states do to win/dominate. First is to increase their own national power and second is to do every possible thing to undermine the development/emergence of other great powers. Following this logic, 
Mearsheimer argued that China has become a regional power, so it would try to push US out of Asia in order to dominate the region itself just like the US dominates the Western hemisphere. Subsequently, US will do everything to prevent China from gaining hegemonic status in Asia. This fight of cat and mouse would give space and options to the developing allies of the two countries.

There would be opportunities also. For example, the Chinese initiatives of One Road One Belt (OBOR) plan an investment of around eight trillion dollars in 65 countries. The Pakistani port of Gwadar would be the gateway of exports (some imports also) of Chinese products to Middle East and the adjoining regions. Therefore, a development hungry Islamabad is receiving a mixture of investment, loans, soft loans and joint ventures of 62 billion dollars, an increase from the 2014 plan of 46 billion dollars. These Chinese plans might be termed as 'economic colonization' or a 'revival of the East India Company', but what it offers is an alliance, an economic interdependence and stability to the poor nations. Beijing would be taking such economic measures to ensure an upper hand in her competition with Washington. Therefore, we can conclude that China is leaving/already left the US economically at least in the region, but militarily, US is still miles ahead. This also has to do with the orientation and priority of the two states: their mode of preferences and choice of partner countries do indicate the winners; US is a military hegemon; China is becoming an economic one.

\section{References}

Bergsten, C. F., Freeman, C., Lardy, N. R., \& Mitchell, D. J. (2008). China's rise: Challenges and opportunities: Peterson Institute.

Cai, P. (2017). Understanding China's Belt and Road Initiative.

Campbell, K., \& Andrews, B. (2013). Explaining the US 'pivot'to Asia. Americas, 1, 1945-1975.

Chan, J. (2013). Chinese strategic review warns of "big power competition" in Asia-Pacific Retrieved 15 February, 2019, from https://www.wsws.org/en/articles/2013/06/06/chin-j06.html

DiCicco, J. M., \& Levy, J. S. (1999). Power shifts and problem shifts: The evolution of the power transition research program. Journal of Conflict Resolution, 43(6), 675-704.

Dobbins, J. (2012). War with China. Survival, 54(4), 7-24.

Downs, E., Becker, J., \& DeGategno, P. (2017). China's Military Support Facility in Djibouti: The Economic and Security Dimensions of China's First Overseas Base: Center for Naval Analyses Arlington United States.

Efird, B., Kugler, J., \& Genna, G. (2003). From war to integration: Generalizing power transition theory. International Interactions, 29(4), 293-313.

Fairbank, J. K., \& Goldman, M. (2006). China: Harvard University Press.

Fogel, R. W. (2007). Capitalism and democracy in 2040: forecasts and speculations: National Bureau of Economic Research Cambridge, Mass., USA.

Glaser, J. (2012). US's China Containment Policy Breeding Resentment, Distrust Retrieved 12 February, 2019, from http://news.antiwar.com/2012/12/17/uss-china-containment-policybreeding-resentment-distrust/ 
Halpin, T. (2009). Brazil, Russia, India and China Form Bloc to Challenge US Dominance Retrieved 20 February, 2019, from www.timesonline.co.uk/tol/news/world/us_and_americas/article6514737.ece.

Hossain, K. (2013). The UNCLOS and the US-China hegemonic competition over the South China Sea. JE Asia \& Int'I L., 6, 107.

Hsiung, J. C. (2008). The New Asian Hemisphere: The Irresistible Shift of Global Power to the East by Kishore Mahbubani. American Foreign Policy Interests, 30(4), 243-244. doi: 10.1080/10803920802314101

Huisken, R. (2009). Rising China: Power and Reassurance: ANU E Press.

Jisi, W. (2011). China's search for a grand strategy: A rising great power finds its way. Foreign Affairs, 68-79.

Kang, D. C. O. (2007). China rising: Peace, power, and order in East Asia: Columbia University Press. Keohane, R. O., \& Nye, J. S. (1977). Power and interdependence: Boston.

Kleven, A. (2015). Is China's Maritime Silk Road A Military Strategy. The Diplomat, 8.

Kugler, J., \& Lemke, D. (1996). Parity and war: Evaluations and extensions of the war ledger: University of Michigan Press.

Lai, D. (2011). The United States and China in power transition: ARMY WAR COLL STRATEGIC STUDIES INST CARLISLE BARRACKS PA.

Layne, C. (1998). Rethinking American grand strategy: hegemony or balance of power in the twentyfirst century? World Policy Journal, 15(2), 8-28.

Lebow, R. N., \& Valentino, B. (2009). Lost in transition: A critical analysis of power transition theory. International Relations, 23(3), 389-410.

Lemke, D., \& Tammen, R. L. (2003). Power transition theory and the rise of China. International Interactions, 29(4), 269-271.

Liff, A. P., \& Erickson, A. S. (2013). Demystifying China's Defence Spending: Less Mysterious in the Aggregate. The China Quarterly, 216, 805-830.

Logan, J. (2013). China, America, and the Pivot to Asia. Cato Institute Policy Analysis(717).

Macfarlane, S. N. (2006). The 'R'in BRICs: is Russia an emerging power? International affairs, 82(1), 41-57.

Manyin, M. E., Daggett, S., Dolven, B., Lawrence, S. V., Martin, M. F., O'Rourke, R., \& Vaughn, B. (2012). Pivot to the Pacific? The Obama administration's rebalancing toward Asia.

Mearsheimer, J. J. (2001). The tragedy of great power politics: WW Norton \& Company.

Miller, S. A. (2017). Donald Trump keeps campaign promise to abandon Trans-Pacific Partnership Retrieved 15 February, 2019, from https://www.washingtontimes.com/news/2017/jan/23/trump-pull-out-trans-pacificpartnership/

Organski, A. (1980). and Jacek Kugler. The War Ledger.

Organski, A. F., \& Kugler, J. (2015). The war ledger: University of Chicago Press.

Organski, A. F. K. (1958). World Politics: Knopf.

Parker, J. W. (2011). Russia's Revival: Ambitions, Limitations, and Opportunities for the United States (Vol. 3): National Defense University Press.

Pu, Y. (2013). Despite its challenges this could be Asia's century. The Asian Century: 
INTERNATIONAL JOURNAL OF ACADEMIC RESEARCH IN BUSINESS AND SOCIAL SCIENCES

Vol. 9, No. 6, June, 2019, E-ISSN: 2222-6990 (C) 2019 HRMARS

Reality or Hype? Retrieved 10 february, 2019, from http://www.internationaleconomy.com/TIE_Su13_AsiaCenturySymposium.pdf

Tammen, R., Kugler, J., Lemke, D., Stam, A., Abdollahian, M., Al-Sharabati, C., Organski, A. (2000). Power transitions. New York: Chatham House.

Tammen, R. L., \& Kugler, J. (2006). Power transition and China-US conflicts. The Chinese Journal of International Politics, 1(1), 35-55.

Tehseen, M. (2017). Sino-US Competition: Implications for South Asia and the Asia-Pacific. Strategic Studies, 37(4).

Trump signs executive order to withdraw US from Trans-Pacific Partnership. (2018) Retrieved 8 February, 2019, from https://www.scmp.com/news/world/united-statescanada/article/2064759/trump-makes-it-official-signs-order-withdraw-us

Wilson, D., \& Purushothaman, R. (2003). Dreaming with BRICs: the path to 2050. Goldman Sachs Global Economics Paper, 99, 1-24.

Zakaria, F. (2009). The Prize Is India: A Relationship Obama Should Nurture. Newsweek, November, $30,51-73$. 